\section{JURNAL ABDIMAS

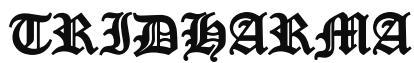

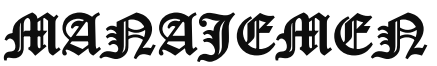

P-ISSN 2615-6849, E-ISSN 2716-070X

Jurnal ABDIMAS Vol. 2,No.3, Agustus 2021,Hal(46-53)

@Prodi Manajemen Fakultas Ekonomi Universitas Pamulang

Email: abdimasjurnal.unpam@gmail.com Telp: (021) 741-2566

\title{
PENYULUHAN STRATEGI PEMASARAN ONLINE DALAM MENGHADAPI PANDEMI COVID-19 DIKELURAHAN CINANGKA, KECAMATAN SAWANGAN, KOTA DEPOK
}

\author{
Aceng Abdul Hamid, Laily Maknin Zubaedah, Ade Irawan ,Nurselvy \\ Dosen Program Studi Teknik Industri, Fakultas Teknik, Universitas Pamulang, \\ Tangerang \\ dosen00958@unpam.ac.id, dosen00651@unpam.ac.id , \\ dosen01235@unpam.ac.id,dosen02045@unpam.ac.id
}

\begin{abstract}
ABSTRAK
Kegiatan Pengabdian Masyarakat (PKM) merupakan salah satu Tridharma Perguruan Tinggi yang wajib dilakukan oleh setiap dosen di Universitas Pamulang. Kegiatan PKM ini bertujuan untuk membantu warga Kelurahan Cinangka dalam berinovasi dengan cara menggali potensi yang ada guna mensejahterakan kehidupan keluarga pada khususnya dan masyarakat pada umumnya. Secara khusustujuan kegiatan PKM (1) Membangkitkan jiwa wirausaha warga dengan caraberinovasi untuk memanfaatkan teknologi untuk melakukan penjualan via online (2) Meningkatkan penghasilan warga di masa pandemi. (3) Memberikanpemahaman strategi pemasaran yang sesuai dengan masa pandemic covid-19. Kegiatan PKM ini dilakukan dengan peninjauan lokasi rencana PKM dan mengetahui permasalahan yang ada di lokasi tersebut dengan cara brainstorming antara dosen dan beberapa pemuka masyarakat. Kemudian TIM PKM menawarkan solusi dari permasalahan yang ada dan disetujui maka dilakukanlah kegiatan PKMini dan diakhir PKM warga akan diberikan kuesioner kepuasan dan perbaikan yangdiperlukan untuk kegiatan PKM lanjutan lainnya.
\end{abstract}

Kata Kunci : Pemasaran online, pandemic covid 19, cinangka

\begin{abstract}
Community Service Activities (PKM) are one of the Tridharma of Higher Education that must be carried out by every lecturer at Pamulang University. This PKM activity aims to assist the residents of Cinangka Village in taking pictures by exploring the existing potential for the welfare of family life in particular and society in general. The objectives of the PKM activity are (1) To generate the entrepreneurial spirit of citizens by utilizing technology to conduct online sales (2) to increase special income during the pandemic. (3) Provide an understanding of marketing strategies in accordance with the covid-19 pandemic. This PKM activity is carried out by designing the location of the PKM plan and knowing the problems that exist in that location by way of brainstorming between lecturers and several communities. Then the PKM TEAM offers solutions to existing problems and it is agreed that this PKM activity is carried out and at the end of the PKM the residents will be given a satisfaction questionnaire and the necessary improvements for other continued PKM activities
\end{abstract}

Keywords: Online marketing, covid 19 pandemic, cinangka 


\section{JURNAL ABDIMAS

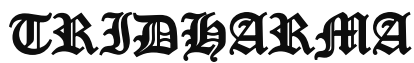 AtA}

\section{A. Pendahuluan}

Kelurahan Cinangka, Kecamatan Sawangan, Kota Depok merupakan daerah yang terletak tepat di dekat Bandara Pondok Cabe dan merupakan perbatasan 3 wilayah yaitu Jakarta Selatan, Tangerang Selatan dan Bogor sehingga membuat Kelurahan Cinangka, Kecamatan Sawangan, Kota Depok menjadi wilayah yang ramai dan padat penduduk. Masyarakat yang tinggal dikawasan ini kebanyakan merupakan perantau dari daerah nusantara. Mereka merantau ke Kelurahan Cinangka, Kecamatan Sawangan, Kota Depok untuk mengadu nasib yang lebih baik. Kebanyakan masyarakatnya sudah berkeluarga dan sudah menetap cukup lama disini. Mayoritas mata pencarian warga Kelurahan Cinangka, Kecamatan Sawangan, Kota Depok pedagang dan karyawan.

Keberhasilan pemasaran suatu produk tidak hanya dinilai dari seberapa banyak konsumen yang berhasil diperoleh namun juga bagaimana cara mempertahankan konsumen tersebut. Dalam pemasaran dikenal bahwa setelah konsumen melakukan keputusan pembelian, ada proses yang dinamakan puas dan tidak puas konsumen terletak pada hubungan antara harapan dengan prestasi yang diterima dari produk atu jasa. Bila produk atau jasa tidak memenuhi harapan konsumen tidak akan melakukan pembelian ulang. Dilain pihak apabila sebuah produk atau jasa melebihi harapan konsumen, maka konsumen akan merasa puas dan memungkinkan untuk melakukan pembelian ulang.

Banyak cara yang melakukan strategi pemasaran. Perkembangan teknologi yang semakin pesatmulai digunakan tidak hanya untuk melakukan tukar informasi, berita, dan semacamnya, namun saat ini teknologi sudah mulai digunakan untuk merambah dan memajukan dunia bisnis.

Teknologi informasi telah menjadi pendukung utama untuk memperoleh informasi dengan sangat cepat dan mudah.
Melalui media ini mereka dapat memperoleh dan menyampaikan berbagaiinformasi yang dibutuhkan kapan dan dimana saja. Jejaring sosial networking sudah semakin majuyang saat ini bisa dikatakan sebagai yang fenomenal adalah twitter dan facebook. dunia maya jugamampu dimanfaatkan untuk membuat seseorang tidak hanya bisa duduk diam tanpa penghasilan, namun dengan internet mereka mampu mendapatkan penghasilan.

Berkembangnya internet banyak hal baru yang timbul dari berkembangnya internet tersebut salah satunya adalah pembelian atau belanja barang ataupun jasa secara online. Internet saat ini dirasa bisa menjadi solusi pemasaran yang sangat bagus karena bisa diakses oleh orang dalam waktuyang tanpa batas $\mathrm{d}$ an bisa diakses oleh orang lain darimana saja berada. Pemasaran media online dapat dikatakan sebagai bisnis yang menjanjikan untuk saat ini. Selain itu internet dapat membantukinerja perusahaan menjadi lebih efektif dan efesien, sehingga dengan meningkatnya kinerja sebuah toko atau perusahaan diharapkan dapat menambah dan mengurangi kesalahan yang disebabkan olehfaktor manusia.

Sejak masa pandemik masyarakat masih kesulitan untuk dapat kembali hidup normal yang dipengaruhi oleh pendapatan yang belum stabil. Hal ini disebabkan kurangnya daya beli masyarakat dipasar, turunnya jumlah pengunjung pasar dan sedikitnya masyarakat yang naik ojek. Apabila dibiarkan berlarut-larut situasi ini akan membuat banyak hal yang terjadi dan berdampak kurang baik nantinya.

Untuk mendorong terjadinya proses transformasi sosial di masyarakat, dari kondisi masyarakat yang tidak berdaya menjadi berdaya, mandiri dan pada akhirnya menuju madani terutama diperkotaan perlu adanya intervensi khusus yakni dilakukan melalui proses saling belajar bukan hanya untuk meningkatkan pengetahuan dan keterampilan akan tetapi juga agar bisa 


\section{JURNAL ABDIMAS

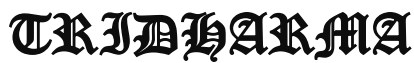

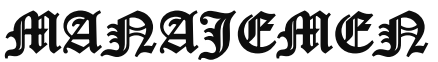

\section{P-ISSN 2615-6849, E-ISSN 2716-070X}

Jurnal ABDIMAS Vol. 2,No.3, Agustus 2021,Hal(46-53)

@ Prodi Manajemen Fakultas Ekonomi Universitas Pamulang

Email: abdimasjurnal.unpam@gmail.com Telp: (021) 741-2566 berbagi nilai-nilai positif. Dengan beberapa pertimbangan yang ada maka kami Dosen Program Studi Teknik Industri memilih melakukan kegiatan Pengabdian Kepada Masyarakat (PKM) di wilayah ini kembali.

PKM merupakan kegiatan wajib dosen yang dilakukan minimal satu kali tiap semester untuk memenuhi salah satu Tri Dharma Perguruan Tinggi yaitu Pengabdian Kepada Masyarakat. Pada kegiatan PKM ini kami berencana mengajarkan Penyuluhan Strategi Pemasaran Online Dalam Menghadapi Pandemi Covid-19 di Kelurahan Cinangka, Kecamatan Sawangan, Kota Depok.

Dengan adanya pandemi covid-19 membuat segala kegiatan terhambat, termasuk kegiatan dagang. Beberapa pedagang kecil yang merupakan warga Kelurahan Cinangka, Kecamatan Sawangan, Kota Depok juga merasakan dampak dari adanya covid 19. Adanya corona membuat para pedagang tidak dapat berjualan seperti biasanya karena adanya pembatasan kegiatan, seperti mengurangi jam operasional toko atau warung serta tidak diperbolehkan adanya kerumunan.

Pemasaran online atau digital marketing merupakan salah satu cara yang tepat untuk meningkatkan penjualan suatu produk di masa pandemi ini. Pemasaran secara online tidak perlu dilakukan secara tatap muka. Pemasaran online dapat dilakukan dengan media sosial seperti Facecook, Whatsapp, dan Instagram.

Diharapkan dengan adanya penyuluhan terkait pemasaran online, para pedagang kecil yang bertempat tinggal di wilayah Kelurahan Cinangka, Kecamatan Sawangan, Kota Depok dapat memahami secara detail mengenai pemasaran online sehingga dapat membawa dampak yang baik yaitu peningkatan penjualan produk.

\section{B. Rumusan Masalah}

Rumusan masalah kegiatan PKM ini secara khusus yaitu:

1. Membangkitkan jiwa wirausaha warga dengan cara berinovasi untuk memanfaatkan teknologi untuk melakukan penjualan via online.

2. Meningkatkan penghasilan warga di masa pandemi

3. Memberikan pemahaman strategi pemasaran yang sesuai dengan masa pandemic covid-19.

\section{Tujuan Kegiatan}

Secara khusus tujuan kegiatan PKM adalah:

1. Membangkitkan jiwa wirausaha warga dengan cara berinovasi untuk memanfaatkan teknologi untuk melakukan penjualan via online.

2. Meningkatkan penghasilan warga di masa pandemi

3. Memberikan pemahaman strategi pemasaran yang sesuai dengan masa pandemic covid-19

\section{Manfaat Kegiatan}

Manfaat umum kegiatan PKM membantu warga Kelurahan Cinangka untuk lebih kreatif dalam memasarkan produk yang dijual dengan cara memanfaatkan teknologi informasi dan berbagai platform serta media sosial yang sesuai dengan produk yang dijual. Secara khusus Manfaat kegiatan PKM adalah:

1. Mendapatkan skill kompetensi dalam penjualan Online

2. Dapat meningkatkan penjualan produk

3. Memecahkan masalah-masalah yang dihadapi oleh pelaku usaha

\section{E. Pemecahan Masalah}

Untuk memecahkan masalah dalam kondisi pandemic yang serba tidak stabil ini adalah warga dituntut untuk selalu belajar, berinovasi, mandiri dan mampu beradaptasi dengan keadaan serta lingkungan. Kegiatan penyuluhan dan pelatihan yang diberikan kepada beberapa perwakilan warga 


\section{JURNAL ABDIMAS

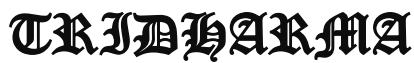 AtA}

P-ISSN 2615-6849, E-ISSN 2716-070X

Jurnal ABDIMAS Vol. 2,No.3, Agustus 2021,Hal(46-53)

@Prodi Manajemen Fakultas Ekonomi Universitas Pamulang

Email: abdimasjurnal.unpam@gmail.com Telp: (021) 741-2566 khususnya ibu-ibu yang dianggap tepat sebagai solusi permasalahan ini. Kegiatan ini bertema "Penyuluhan Strategi Pemasaran Online Dalam Menghadapi Pandemi Covid-19 di Kelurahan Cinangka, Kecamatan Sawangan, Kota Depok".

\section{F. Tinjauan Pustaka}

1. Pemasaran

Pemasaran merupakan salah satu lini penting dalam bisnis, sebuah produk mulai diperkenalkan hingga didistribusikan hingga sampai ke tangan konsumen merupakan tugas dari bagian pemasaran. Banyak metode atau cara yang dapat digunkan untuk memasarkan barang atau jasa. Tim pemasaran harus jeli dalam menentukan metode apa yang sesuai untuk memasarkan produknya. Metode pemasaran yang sesuai mempengaruhi penerimaan produk atau jasa dipasaran. Seiring dengan perkembangan zaman yang sangat dinamis ini maka tim pemasar harus selalu merupak pola pemsaran agar dapat bersaing dipasar bebas dengan kompetitornya.

\section{Strategi}

Strategi adalah pendekatan secara keseluruhan yang berkaitan dengan gagasan, perencanaan, dan eksekusi, sebuah aktivitas dalam kurun waktutertentu. Di dalam strategi yang baik terdapat kordinasi tim kerja, memiliki tema mengidentifikasi faktor pendukungnya sesuai dengan prinsip-prinsip pelaksanaan gagasan secara rasional, efesiensi dalam pendanaan dan memiliki taktik untuk mencapai tujuan secara efektif

\section{Strategi Pemasaran}

Strategi pemasaran merupakan salah satu penentu lakunya produk dipasaran. Strategi pemasaran yang benar akan meark minat konsumen terhadapproduk yang ada. Digital marketing atau pemasaran secara digital merupakan salah satu mediapemasaran yang diminati saat ini (Pradiani, 2017) khususnya masa pandemic paling banyak dan berhasil digunakan untuk menjual produk. Menurut
Pradiani(2017), masyarakat saat ini mulai meninggalkan pemasaran tradisional dan beralih ke pemasaran digital karena pemasaran digital komunikasi dan transaksi dapat dilakukan setiap waktu/real time dan dapat mengglobal dalam waktu yangsingkat. Mudahnya penggunaan pemasaran digital ini dapat membantupengusaha pemula atau UMKM untuk mengembangkan pasarnya.

\section{G. Metode Pelaksanaan}

Tahap-tahap yang dilakukan dalam kegiatan ini meliputi:

1. Survei awal Survei ke lokasi Cinangka

2. Fiksasi Jadwal Penentuan waktu kegiatan.

3. Persiapan Materi Kegiatan Penyusunan bahan/materi kegiatan yang meliputi: slide powerpoint, handout dan door prise.

4. Pelaksanaan Pelaksanaan PKM ini meliputi :

a. Penyuluhan interaktif secara online melalui aplikasi zoom meeting kegiatannya yaitu sosialisasi (pemaparan materi). Dipandu oleh Dr. Aceng Abdul Hamid, S.T., M.M

b. Penyuluhan dan pelatihan oleh Laily Maknin Z, S.T., M.B.A.

c. Koordinator peserta dalam kegiatan Tanya jawab oleh Ade Irawan, S.T., M.M.

\section{H. Hasil dan Pembahasan}

Kegiatan pengabdian kepada masyarakat ini dilakukan secara online melalui aplikasi zoom meeting dengan konsep Webinar dikarenakan dalam kondisi pandemi Covid 19. Kegiatan PKM ini dihadiri oleh 4 Dosen dan 3 Mahasiswa Program Studi Teknik Industri Universitas Pamulang serta 25 Peserta yang terdiri dari Lurah Cinangka, Ketua RW, Ketua Karang Taruna, Ketua 


\section{JURNAL ABDIMAS

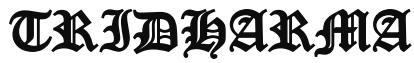 AtA}

\section{P-ISSN 2615-6849, E-ISSN 2716-070X}

Jurnal ABDIMAS Vol. 2,No.3, Agustus 2021,Hal(46-53)

@ Prodi Manajemen Fakultas Ekonomi Universitas Pamulang

Email: abdimasjurnal.unpam@gmail.com Telp: (021) 741-2566
RT dan para pelaku UMKM di Kelurahan Cinangka Kecamatan Sawangan Kota Depok.

Kegiatan PKM diawali dengan pemaparan terkait kegiatan yang akan dilaksanakan. Kegiatan ini dimuai dengan sambutan dari Dr. Aceng Abdul Hamid, S.T., M.M. PKM merupakan bentuk pengabdian dosen kepada masyarakat sebagai salah satu bentuk Tri Dharma Perguruan Tinggi.

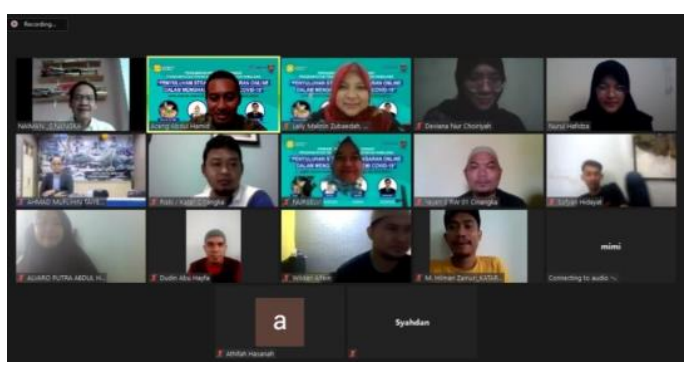

Gambar 1. Sambutan oleh Ketua PKM

Acara PKM ini pun dibuka langsung oleh Lurah Cinangka yaitu Bapak Naiman, S.Pd., M.Si. Acara Webinar ini diharapkan dapat memberikan wawasan dan peluang baru bagi para UMKM yang ada di wilayah kelurahan Cinangka untuk dapat menjual produknya dan meningkatkan penjualan denganmenggunakan teknologi informasi

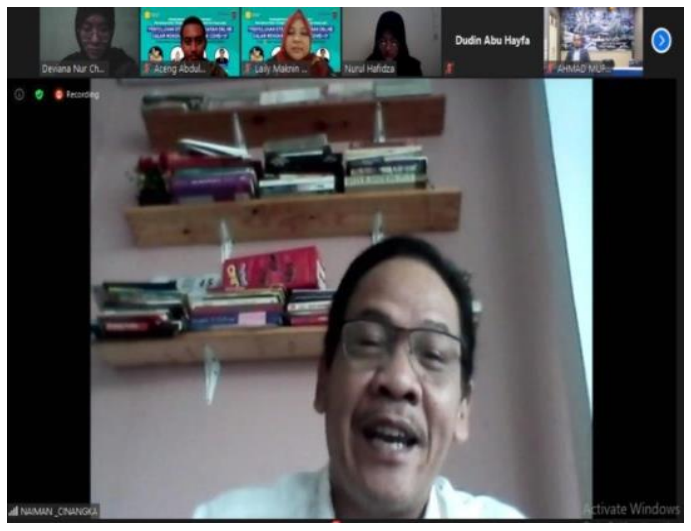

Gambar 2. Pembukaan Webinar oleh Lurah Cinangka

Setelah Pembukaan, kemudian MC melanjutkan acara ke acara inti yaitu pemaparan materi PKM dengan tema
"Strategi Penjualan Online Dimasa Pandemic Covid-19”. Penyampaian materi oleh para narasumber ini akan dipandu oleh Moderator dari Dosen Teknik Industri Universitas Pamulang yaitu Dr. Aceng Abdul Hamid, S.T., M.M., CMA., CH., CHt. Serta memandu proses tanya jawab dari para peserta ke Narasumber.

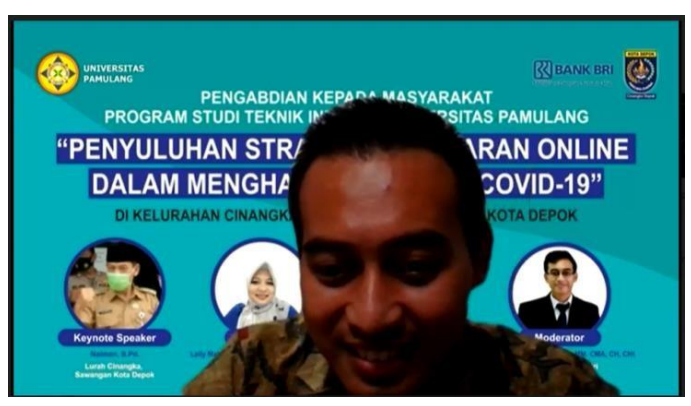

Gambar 4. Moderator Webinar Dr. Aceng Abdul Hamid, S.T., M.M.

Materi pertama yaitu mengenai Digital Marketing Dobrak Kebuntuan di Era Pandemi dengan narasumber Bapak Ahmad Muflihin Taiyeb, ST., MBA. beliau adalah Kepala Cabang Bank BRI CEPU yang diharpkan agar memberikan pandangan terhadap kondisi Pandemi Covid-19 dan solusinya.

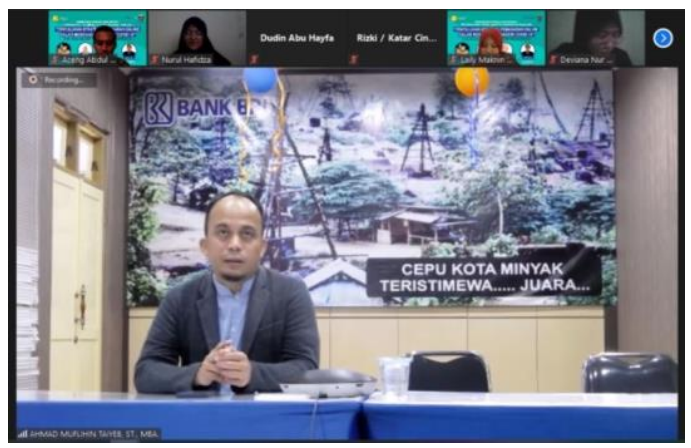

Gambar 5. Pemaparan Materi oleh Ahmad Muflihin Taiyeb, ST., MBA.

Setelah medengar pemaparan materi ini diharapkan dapat memberikan wawasan dan peluang baru bagi para pelaku UMKM di Kelurahan Cinangka. Setelah memahami materi ini para pelaku peserta mulai untuk 


\section{JURNAL ABDIMAS

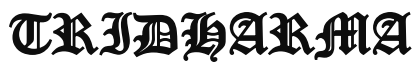

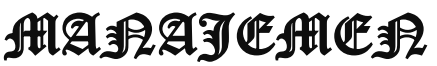

\section{P-ISSN 2615-6849, E-ISSN 2716-070X}

Jurnal ABDIMAS Vol. 2,No.3, Agustus 2021,Hal(46-53)

@ Prodi Manajemen Fakultas Ekonomi Universitas Pamulang

Email: abdimasjurnal.unpam@gmail.com Telp: (021) 741-2566 mengindentifikasi kondisi usahanya dan membuat analisis untuk mengetahui strategi yang akan dilakukan untuk mengembangka usahanya dalam kondisi pandemic-19 ini yangtak kunjung berakhir.

Materi kedua ini yang bertema Strategi Jitu Pemasaran Melalui Sosial Media dengan narasumber yaitu Ibu Laily Maknin Zubaedah, ST., MBA., CT., CMA. pada materi kedua mengupas tuntas dalam pemanfaatan media sosial sebagai media promosi. Di awali dengan pengertian media sosial, pengertian promosi, tujuan promosi, advertising, jenis kegiatan promosi, pesan dalam promosi. Pemaparan materi diberikan dalam 15 menit dimana setalah pemaparan materi selsai akan dilakukan sesi tanya jawab. Sesi tanya jawab dibagi menjadi 2 sesi yaitu terdiri sesi hanya tiga pertanyaan dan sesi kedua hanya 3 pertanyan. Sesi tanya jawab ini dilaksankan untuk memancing keaktifan para peserta yang mengikuti kegiatan ini. Selain itu setiap peserta dalam kegiatan penyuluhan ini mendapatkan materi

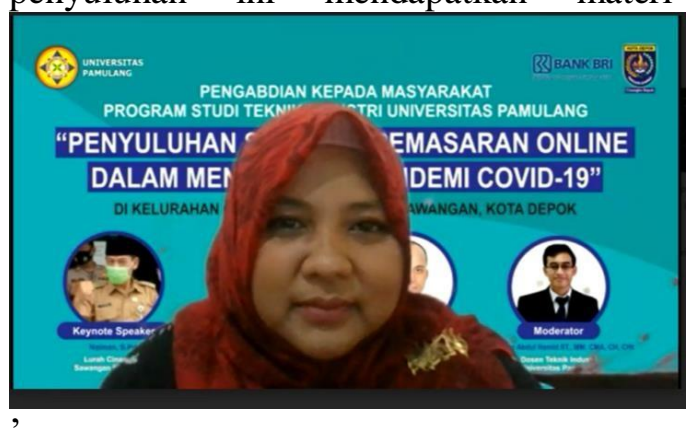

Gambar 6. Laily Maknin Zubaedah, ST., MBA., CT., CMA

Dalam kondisi yang serba dibatasi dengan adanya pandemic ini, maka secara langsug berpengaruh terhadap proses penjualan terutama bagi para pelakuusaha kecil, sesuai yang sudah dipaparkan pada pemateri 1 . Oleh karena itu perlu dilakukan strategi pemasaran yang tepat dengan Strategi Media Sosial Marketing Untuk Bisnis Berskala Kecil, dimana startegi yang harus dilakukan adalah sebagai berikut ini:
1. Membangun Kredibilitas

2. Menarik Pelanggan Potensial

3. Membangun Relasi di Media Sosial

4. Membagikan Konten yang Sesuai

5. Membuat Konten yang Valueable

6. Menggunakan Gambar yang Baik dan Menarik

7. Crowdsource Untuk Konten Menarik dan otentik

8. Berpartipasi Dalam Kelompok dan Komunitas

9. Berinteraksi dengan Follower

10. Fokus Pada Beberapa Platfrom Sosial Media yang Potensial

Dengan strategi diatas maka diharapkan para pelaku UMKM di Kelurahan Cinangka dapat memahami dan menerapkannya, agar usahanya tetap berjalan dan bahkan lebih berkembang.

\section{Kesimpulan dan Saran}

\section{Kesimpulan}

Pelaksanaan kegiatan Pengabdian Kepada Masyarakat oleh lembaga Penelitian dan Pengabdian Masyarakat (LPPM) Universitas Pamulang yang dilakukan oleh dosen-dosen Teknik Industri ini berjalan dengan lancar dan mendapat sambutan yang positif dari Warga Kelurahan Cinangka, Karang Taruna, serta para pelaku usaha dilingkungan Kelurahan Cinangka. Dari kegiatan PKM ini dapat ditarik beberapa kesimpulan :

a. Kegiatan PKM ini dapat menambah pengetahuan bagi para pelaku usaha maupun yang akan memulai usaha dalam menghadapi pandemic covid19.

b. Kegiatan PKM ini menambah keterampilan warga Kelurahan Cinangka dalam memasarkan produknya melalui berbagai platform media social.

c. Kegiatan PKM ini memberikan pemahaman strategi pemasaran yang sesuaidengan kondisi pandemi. 


\section{JURNAL ABDIMAS

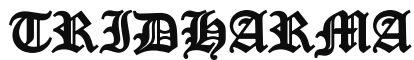

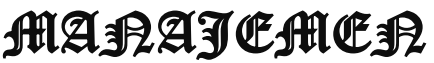

\section{P-ISSN 2615-6849, E-ISSN 2716-070X}

Jurnal ABDIMAS Vol. 2,No.3, Agustus 2021,Hal(46-53)

@ Prodi Manajemen Fakultas Ekonomi Universitas Pamulang

Email: abdimasjurnal.unpam@gmail.com Telp: (021) 741-2566

\section{Saran}

Dari pelaksanaan kegiatan PKM ini ada beberapa saran:

a. PKM dapat dilakukan berkelanjutan untuk menjaga semangat wirausaha masyarakatnya.

b. Melakukan pendampingan kepada Warga Kelurahan Cinangka yang masih kesulitan dalam mengimplementasikan materi PKM.

c. Melakukan monitoring kepada peserta yang mengikuti PKM untuk memastikan bahwa peserta dapat mengimplementasikan materi yang sudah didapatkan di PKM.

\section{J. Daftar Pustaka}

Handayani, Novi. Dkk. 2018. Pengaruh Influencer Marketing Sebagai strategi Pemasaran digital era Modern (Sebuah Strategi Literatur). JurnalEKSEKUTIF Volume 15, no 1 Juni 2018.

Khasali, R. (2018). Strawberry Generation. Jakarta: Mizan.

Oktavianita, Bella. Dkk. 2020. Pengembangan Ekonomi Desa Padanaan dengan Wirausaha Keripik Kulit pisang di Kabupaten Sumedang. Jurnal Pusat Inovasi Masyarakat ISSN 2721-897X: Juni 2020, Vol 2(4) 2020:690-695.

Pasaribu, V. L. D., Agrasadya, A., Shabrina, N., \& Krisnaldy, K. (2020). Menjadi Enterpreneur Muda Yang Memiliki Jiwa Leadership Untuk Menghadapi Masa Depan. Abdi Laksana: Jurnal Pengabdian Kepada Masyarakat, 1(1).

Pasaribu, V. L. D., Susanti, F., \& Hartuti, E. T. K. (2019). Memotivasi Siswa dan Siswi SMK Letris Indonesia di
Dalam Menentukan Pilihan Untuk

Melanjutkan Pendidikan Atau Bekerja Setelah Lulus Sekolah. Jurnal Pengabdian Dharma Laksana, 1(2), 161-172.

Pasaribu, V. L. D., Sulaiman, S., Sutiman, S., Thaharudin, T., \& Purnomo, B. Y. (2020). Pengenalan Letak Posyandu Terdekat Dikelurahan Pisangan Dengan Manajemen Pemasaran Revolusi 4.0 Untuk Meningkatkan Pengetahuan Masyarakat Letak Dan Fungsi Posyandu Terdekat Pada Kelurahan Pisangan. Dedikasi Pkm, l(1), 105110.

Pasaribu, V. L. D., Oktrima, B., Prabowo, B., Arianto, N., \& Haryoko, U. B. (2020). Progam Pendampingan Dan Penyelenggaraan Pendidikan Anak Pada Usia Dini Terhadap Prestasi Belajar Dilingkungan Rt $020 \mathrm{Rw}$ 009. Kel Giri Peni. Kec Wates. Yogyakarta. Jurnal Lokabmas Kreatif, 1(1), 71-75.

Pasaribu, V. L. D., Jannah, M., Fazar, M., Putra, S. P., Monalisa, M., \& Sofa, M. (2021). MENINGKATKAN PRODUKTIVITAS USAHA DIMASA PANDEMI PADA IBU PKK RT 004/003 KELURAHAN SAWAH BARU CIPUTAT, TANGERANG SELATAN. Abdi Laksana: Jurnal Pengabdian Kepada Masyarakat,2(2), 295301.

Pasaribu, V. L. D., Yuniati, H. L., Pranata, R., Sembayu, R., Purba, S. M., \& Nurbayani, T. T. A. (2021). MANAJEMEN KEUANGAN 


\section{JURNAL ABDIMAS

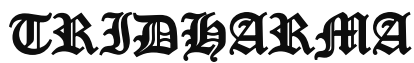

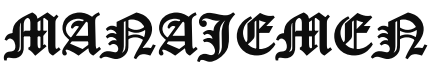

\section{P-ISSN 2615-6849, E-ISSN 2716-070X}

Jurnal ABDIMAS Vol. 2,No.3, Agustus 2021,Hal(46-53)

@Prodi Manajemen Fakultas Ekonomi Universitas Pamulang

Email: abdimasjurnal.unpam@ gmail.com Telp: (021) 741-2566
UNTUK MENGHADAPI DAN

BERTAHAN DI ERA COVID

19. Jurnal Abdimas Tri Dharma

Manajemen, 2(2), 12-18.

Pasaribu, V. L. D., Dwiyatni, A., Sabina, C., Ridwan, M., Gunawan, D. D., \& Noviani, B. C. (2021). EVALUASI PENERAPAN 3M DIMASA PANDEMIC COVID 19. Jurnal Abdimas Tri Dharma Manajemen, 2(2), 54-60.

Pasaribu, V. L. D., Syafei, A. N., Farhan, A., Aufaizah, A., Irani, C., \& Firtiayani, S. R. (2021). PENGARUH DISPLIN PROTOKOL KESEHATAN TERHADAP PENCEGAHAN PENULARAN VIRUS COVID19. Jurnal Abdimas Tri Dharma Manajemen, 2(2), 91-98.

Pasaribu, V. L. D., Septiani, F., Rahayu, S., Lismiatun, L., Arief, M., Juanda, A., ... \& Rahim, R. (2021). Forecast Analysis of Gross Regional Domestic Product based on the Linear Regression Algorithm Technique.

Priadi, A., Pasaribu, V. L. D., Virby, S., Sairin, S., \& Wardani, W. G. (2020). Penguatan Ekonomi Kreatif Berbasis Sumber Daya Desa Dikelurahan Rempoa. Abdi Laksana: Jurnal Pengabdian Kepada Masyarakat, 1(3), 356-35

Pradiani, Theresia. 2017. Pengaruh Sistem Pemasaran Digital Marketing Terhadap Peningkatan Volume Penjualan Hasil Industri Rumahan. JIBEKA Volume 11 Nomor 2 Februari 2017 : 46-53.
Prasetyo, Hoedi dan Sutopo, Wahyudi.2018.Industri 4.0: Telaah klasifikasi aspek dan arah perkembangan riset. Jurnal Teknik Insdustri (J@TI). Volume 13.No.1. Halaman 17-18.

Rezasyah, Teuku. Ivan dan Affabile.2018. Kesiapan Siswa SMK dalam Revolusi Industri 4.0. Jurnal Pengabdian Kepada Masyarakat. Kumawula, Vol. 1, No.2, Agustus 2018, Hal $114-119$.

Shwab, K. (2016). The Fourth Industrial Revolution. New York: Crown Business.

Tim Universitas Pamulang. 2020. http://unpam.ac.id/visi-dan-m 


\section{JURNAL ABDIMAS \\ P-ISSN 2615-6849, E-ISSN 2716-070X

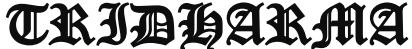 \\ Jurnal ABDIMAS Vol. 2,No.3, Agustus 2021,Hal(46-53)

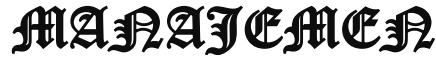 \\ @Prodi Manajemen Fakultas Ekonomi Universitas Pamulang \\ Email: abdimasjurnal.unpam@gmail.com Telp: (021) 741-2566}

